\title{
Physiological and Nutritional Features of Corynebacterium pyogenes
}

\author{
By C. ADINARAYANA REDDY* AND C. P. CORNELL \\ Department of Microbiology and Public Health, Michigan State University, East Lansing, \\ Michigan 48824, U.S.A.
}

(Received 12 November 1981; revised 26 May 1982)

\begin{abstract}
Growth and acid metabolic products were similar when Corynebacterium pyogenes was grown aerobically or anaerobically in a serum-free medium (SFM). This indicated that $C$. pyogenes obtains energy for growth primarily by fermentative metabolism even under aerobic growth conditions. Growth yield was reduced by $90 \%$ in SFM minus glucose, $50 \%$ in SFM minus $\mathrm{NaHCO}_{3}, 90 \%$ in SFM minus yeast extract, $100 \%$ in SFM minus Trypticase and yeast extract, and $30 \%$ in SFM minus haemin or Trypticase. Growth was not detectable when a known mixture of amino acids, vitamins, and nucleic acid bases were substituted for Trypticase and yeast extract in SFM; addition to the latter medium of a peptide source such as Trypticase or casitone supported good growth of the organism. When $\mathrm{NaHCO}_{3}$ was omitted from SFM and dissolved $\mathrm{CO}_{2}$ in the medium was rigorously excluded, growth was undetectable indicating that $C$. pyogenes has an obligate requirement for $\mathrm{CO}_{2}$ for growth. Succinate, formate and acetate were the major fermentation products in SFM, whereas in SFM minus $\mathrm{HCO}_{3}^{-}$or haemin, lactate was the major product and only small quantities of other acids accumulated.
\end{abstract}

\section{INTRODUCTION}

Corynebacterium pyogenes (Cummins et al., 1974) is frequently isolated from a wide variety of pyogenic conditions in animals (Bruner \& Gillespie, 1973; Buxton \& Fraser, 1977; Smith, 1966) and humans (Chlosta et al., 1970; Vega \& Gavan, 1970). Previous physiological, nutritional and metabolic studies of this organism have been limited because it grew poorly on common laboratory media unless supplemented with complex nutritional sources such as blood or serum (Bruner \& Gillespie, 1973; Cummins et al., 1974). Haemin partially replaces the requirement for blood or serum for growth (Reddy et al., 1977; Skerman, 1966), and serum-free media which support good growth of this organism have been described (Reddy et al., 1980). We describe here some physiological and nutritional features of $C$. pyogenes, determined in a serum-free medium.

\section{METHODS}

Bacteria. Corynebacterium pyogenes strain 5 (ATCC 33157), used throughout this study, has been described previously (Reddy et al., 1977). Bacteroides fragilis subsp. fragilis (ATCC 25285) was obtained from American Type Culture Collection, Rockville, Md.

Maintenance. The organism was maintained on plates of Brain Heart Infusion (BBL) agar supplemented with $5 \%(\mathrm{v} / \mathrm{v})$ bovine blood as previously described (Reddy et al., 1977).

Media. The serum-free medium (SFM) contained per $100 \mathrm{ml}$ : glucose, $0.4 \mathrm{~g}$; Trypticase (BBL), $0.5 \mathrm{~g}$; yeast extract (Difco), $0.2 \mathrm{~g}$; haemin, $0.0002 \mathrm{~g}$; mineral solutions 1 and $2,7.5 \mathrm{ml}$ each; volatile fatty acid solution, $1.0 \mathrm{ml}$; $1 \mathrm{M}$-potassium phosphate buffer $(\mathrm{pH} 7.0), 2.0 \mathrm{ml}$; cysteine $\mathrm{HCl} .2 \mathrm{H}_{2} \mathrm{O}, 0.05 \mathrm{~g}$, and $\mathrm{NaHCO}_{3}, 0.4 \mathrm{~g}$. The composition of the mineral solutions 1 and 2 were as described by Caldwell \& Bryant (1966). The volatile fatty acid solution contained per $100 \mathrm{ml}: 1.6 \mathrm{ml}$ acetic acid, and $1 \mathrm{ml}$ each isobutyric, DL- $\alpha$-methylbutyric and $n$-valeric acids. SFM was initially prepared under strict anaerobic conditions, using Hungate anaerobic techniques as modified by Holdeman \& Moore (1975). This anaerobic SFM additionally contained $0.0001 \%$ resazurin as an $E_{\mathrm{h}}$ indicator and was sufficiently reduced to keep the resazurin colourless; it supported good growth $\left(A_{600}=1 \cdot 3\right.$ in $24 \mathrm{~h}$ ) of an obligate anaerobe, B. fragilis.

Abbreviations: MSFM, Modified serum-free medium; SFM, serum-free medium. 
Preliminary experiments showed no difference in growth of $C$. pyogenes in anaerobic SFM and aerobic SFM (prepared aerobically and incubated statically in foam-plugged tubes). Therefore, the aerobic SFM was used in all further studies except where indicated otherwise. Aerobic SFM was prepared as follows. All components except cysteine and $\mathrm{HCO}_{3}^{-}$were dissolved in water, adjusted to $\mathrm{pH} 6.5$ with $5 \mathrm{M}-\mathrm{NaOH}$, dispensed in $18 \times 150 \mathrm{~mm}$ foamplugged tubes $\left(9.5 \mathrm{ml}\right.$ per tube) and sterilized by autoclaving at $121{ }^{\circ} \mathrm{C}$ for $15 \mathrm{~min}$. Cysteine and $\mathrm{HCO}_{3}^{-}$solutions were autoclaved separately and were added aseptically to the medium immediately prior to inoculation.

Modified SFM medium (MSFM), used for demonstrating the peptide requirement for growth of $C$. pyogenes (Expt 4, Table 1) was identical to SFM except that yeast extract and Trypticase were omitted and $1 \mathrm{ml}$ each of purines and pyrimidines, trace minerals, and vitamin solutions were added. The composition of these three stock solutions was described previously (Reddy et al., 1980). In addition, $10 \mathrm{ml}$ stock solution of a defined mixture of free amino acids (Reddy et al., 1980) were added to MSFM where indicated. Trypticase and other peptide sources added to MSFM were treated with charcoal to remove nucleotides and vitamins (Ford et al., 1958). Trypticase and casitone (Difco) were added to MSFM to give a final concentration of $0.5 \%(\mathrm{w} / \mathrm{v})$ and unhydrolysed casein was added to $0 \cdot 1 \%(\mathrm{w} / \mathrm{v})$.

To study the $\mathrm{CO}_{2}$ requirement of $C$. pyogenes, $\mathrm{NaHCO}_{3}$ was omitted from $\mathrm{SFM}$ and dissolved $\mathrm{CO}_{2}$ in the medium was rigorously excluded as previously described by Dehority (1971), except that the pH during the initial removal of dissolved $\mathrm{CO}_{2}$ was 5.5. A BioFlo fermenter (model C30, New Brunswick Scientific Co.) containing $550 \mathrm{ml}$ of medium at $37{ }^{\circ} \mathrm{C}$ was sparged with $100 \% \mathrm{~N}_{2}$ or $90 \% \mathrm{~N}_{2}+10 \% \mathrm{CO}_{2}$ as indicated in the results (Expt 2, Table 1). SFM medium sparged with $100 \% \mathrm{CO}_{2}$ was used as a positive control.

Growth measurements. All media were first inoculated with one drop (about $0.05 \mathrm{ml})$ of an SFM culture $\left(A_{600}=\right.$ 1.4 to 1.6 ). To minimize carryover of nutrients, subsequent subcultures were inoculated with bacteria grown in respective nutritional media whenever possible. Tubes were incubated statically at $37^{\circ} \mathrm{C}$. Growth in all cases was measured in $18 \times 150 \mathrm{~mm}$ tubes by determining the $A_{600}$ with a Bausch and Lomb Spectronic-20 spectrophotometer. $A_{600}$ of 1.0 corresponded to $1.83 \pm 0.18 \times 10^{9}$ cells of C. pyogenes $\mathrm{ml}^{-1}$ or $0.45 \mathrm{mg} \mathrm{dry} \mathrm{wt} \mathrm{ml}^{-1}$. Absorbance values represent the mean of maximal $A_{600}$ values of triplicate tubes from at least two separate experiments.

Culture purity was determined periodically by examination of Gram-stained smears, examination of wet mounts by phase contrast microscopy and colony morphology on Brain Heart Infusion blood agar plates.

Gas chromatography. Cultures in the stationary phase of growth were acidified and volatile and non-volatile acids were extracted as described by Holdeman \& Moore (1975). A Varian 2440 gas chromatograph with thermal conductivity detectors and a column $(3 \mathrm{~mm} \times 2 \mathrm{~m})$ containing $15 \%(\mathrm{w} / \mathrm{w}) \mathrm{SP} 1220 / 3 \%(\mathrm{w} / \mathrm{v}) \mathrm{H}_{3} \mathrm{PO}_{4}$ on Chromosorb (Supelco, Bellefonte, Pa.) was used. Helium ( $25 \mathrm{ml} \mathrm{min}^{-1}$ ) was the carrier gas. The temperature of the column was $135^{\circ} \mathrm{C}$. Concentrations of fermentation products were determined by comparing their retention times and peak heights to retention times and peak heights of standard concentrations of known acids under the same experimental conditions.

\section{RESULTS AND DISCUSSION}

\section{Yields during aerobic and anaerobic growth in SFM}

Corynebacterium pyogenes is generally described as aerobic to facultatively anaerobic (Cummins et al., 1974), but growth of this organism under strictly anaerobic conditions has not previously been described. The yields were about the same $\left(0.68 \mathrm{mg}\right.$ dry wt $\left.\mathrm{ml}^{-1}\right)$ whether $C$. pyogenes was grown under strictly anaerobic conditions or aerobically. The major acidic fermentation products in both cases were acetate, succinate and formate; minor products were lactate and pyruvate.

It is probable that the bottom of tubes from which oxygen was not rigorously excluded was anaerobic. The organism was therefore grown in a BioFlo fermenter aerated with $600 \mathrm{ml} \mathrm{min} \mathrm{m}^{-1}$ of a mixture of $95 \%$ air $/ 5 \% \mathrm{CO}_{2}$ to demonstrate conclusively that $C$. pyogenes can grow aerobically. The $\mathrm{CO}_{2}$ in the gas mixture is needed to replenish the loss of $\mathrm{HCO}_{3}^{-}$due to sparging of SFM. Growth in the fermenter was essentially identical to that seen in SFM tubes (Expt 1, Table 1). The final $\mathrm{pH}$ of 6.0 in the fermenter was comparable to that observed in the tubes. These results indicate that aerobic respiration is not a major source of energy for this organism and that growth is primarily fermentative even in aerated media.

\section{Growth requirements of $C$. pyogenes}

Omission of glucose from SFM resulted in about a $90 \%$ decrease in yield compared to that observed in SFM (Expt 3, Table 1) even though the medium is rich in peptones and $C$. pyogenes 
Table 1. Effect of air, $\mathrm{CO}_{2}$, peptide sources and various components of SFM on growth of

$$
\text { C. pyogenes }
$$

Experiments 1 and 2 were performed in a BioFlo fermenter as described in Methods. The medium was continuously sparged with $\mathrm{N}_{2}, \mathrm{~N}_{2} / \mathrm{CO}_{2}$ or air/ $\mathrm{CO}_{2}$. In experiment 2 , after $96 \mathrm{~h}$ incubation, the gas phase was shifted from $100 \% \mathrm{~N}_{2}$ to $90 \% \mathrm{~N}_{2} / 10 \% \mathrm{CO}_{2}$. Experiments 3 and 4 were performed in $18 \times$ $150 \mathrm{~mm}$ foam-plugged tubes. Growth yields were calculated from absorbance values at $600 \mathrm{~nm}$. $\left(A_{600}\right.$ of $1.0=0.45 \mathrm{mg} \mathrm{dry} \mathrm{wt} \mathrm{ml}^{-1}$ ). Numbers in parentheses are $\mathrm{h}$ incubation required for maximum growth.

\begin{tabular}{|c|c|c|c|c|}
\hline Expt & Medium* & Gas phase & $\begin{array}{l}\text { Growth rate } \\
\left(\mu_{\max } \mathrm{h}^{-1}\right) \dagger\end{array}$ & $\begin{array}{l}\text { Growth yield } \\
\left(\mathrm{mg} \mathrm{ml}^{-1}\right)\end{array}$ \\
\hline 1 & $\begin{array}{l}\text { SFM } \\
\text { SFM }\end{array}$ & $\begin{array}{l}95 \% \text { air } / 5 \% \mathrm{CO}_{2} \\
95 \% \mathrm{~N}_{2} / 5 \% \mathrm{CO}_{2}\end{array}$ & $\begin{array}{l}0.63 \\
0.63\end{array}$ & $\begin{array}{l}0.68(24) \\
0.72(26)\end{array}$ \\
\hline 2 & $\begin{array}{l}\text { SFM } \\
\text { SFM }\end{array}$ & $\begin{array}{l}100 \% \mathrm{~N}_{2} \\
90 \% \mathrm{~N}_{2} / 10 \% \mathrm{CO}_{2}\end{array}$ & - & $\begin{array}{l}0 \cdot 01 \\
0.61(30)\end{array}$ \\
\hline 3 & $\begin{array}{l}\text { SFM } \\
\text { SFM - NaHCO } \\
\text { SFM - haemin } \\
\text { SFM - YE } \\
\text { SFM - Try } \\
\text { SFM - Glu } \\
\text { SFM - Try \& Glu } \\
\text { SFM - Try \& Cys } \\
\text { SFM - Glu \& Cys } \\
\text { SFM - Try \& YE } \\
\text { SFM - Try, YE \& Cys }\end{array}$ & $\begin{array}{l}\text { Air } \\
\text { Air } \\
\text { Air } \\
\text { Air } \\
\text { Air } \\
\text { Air } \\
\text { Air } \\
\text { Air } \\
\text { Air } \\
\text { Air } \\
\text { Air. }\end{array}$ & $\begin{array}{l}0 \cdot 63 \\
0 \cdot 12 \\
0 \cdot 24 \\
0 \cdot 10 \\
0 \cdot 40 \\
0 \cdot 19 \\
0 \cdot 40 \\
0 \cdot 50 \\
0 \cdot 50 \\
\text { NG } \\
\text { NG }\end{array}$ & $\begin{array}{l}0.69(18) \\
0.32(42) \\
0.45(48) \\
0.09(18) \\
0.45(31) \\
0.08(30) \\
0.04(20) \\
0 \cdot 14(40) \\
0.08(28) \\
- \\
-\end{array}$ \\
\hline 4 & $\begin{array}{l}\text { MSFM } \\
\text { MSFM + aa } \\
\text { MSFM + Try } \\
\text { MSFM + aa + Try } \\
\text { MSFM + aa + Cas } \\
\text { MSFM + aa + casein }\end{array}$ & $\begin{array}{l}\text { Air } \\
\text { Air } \\
\text { Air } \\
\text { Air } \\
\text { Air } \\
\text { Air }\end{array}$ & $\begin{array}{l}- \\
- \\
- \\
-\end{array}$ & $\begin{array}{l}0 \cdot 02 \\
0 \cdot 11 \\
0 \cdot 50 \\
0 \cdot 68 \\
0 \cdot 68 \\
0 \cdot 18\end{array}$ \\
\hline
\end{tabular}

* aa, Amino acids; Cas, casitone; Cys, cysteine; Glu, glucose; Try, Trypticase (BBL); YE, yeast extract. $\dagger$ NG, No growth.

is proteolytic (Barksdale, 1970; Bruner \& Gillespie, 1973; Cummins et al., 1974). Similar yields were obtained even after eight serial transfers when glucose was omitted from SFM. When glucose was replaced by cellobiose, fructose, glycogen, lactose, maltose or ribose, normal growth yields comparable to that in SFM were obtained. However, amino acids such as alanine, arginine, aspartate, glycine, or threonine gave no more growth than that seen in SFM minus glucose. These data indicate that $C$. pyogenes requires a fermentable carbohydrate as its primary source of energy and that it obtains little or no energy from the amino acids or peptides present in SFM. The low but consistent growth in glucose-deficient SFM is probably due to low concentrations of carbohydrate present in yeast extract (Anonymous, 1973).

Omission of yeast extract, which is a source of vitamins, nucleotides and amino acids resulted in a decrease in growth yield of approximately $90 \%$ with decrease in the rate of growth (Expt 3 , Table 1).

The growth yield in SFM minus Trypticase was about 65 to $70 \%$ of that in the complete SFM and was undetectable when both Trypticase and yeast extract were omitted (Expt 3, Table 1). This indicated that yeast extract and Trypticase can partially substitute for each other in satisfying the nitrogen and other requirements for growth of $C$. pyogenes, and that cysteine and $\left(\mathrm{NH}_{4}\right)_{2} \mathrm{SO}_{4}$ in the medium cannot, by themselves, satisfy the nitrogen requirements for the growth of this organism.

The growth yield decreased by $60 \%$ when cysteine was omitted (data not shown), comparable to the decrease when Trypticase was omitted, but by $80 \%$ when both Trypticase and cysteine were omitted. In the latter case, the incubation time required to attain maximum growth was $40 \mathrm{~h}$, about twice that in SFM (Table 1). 
Omission of haemin or $\mathrm{HCO}_{3}^{-}$resulted in approximately $30 \%$ and $50 \%$ decrease in growth yields, respectively (Expt 3, Table 1) with considerable decrease in the growth rate. Compared to a doubling time of $1.6 \mathrm{~h}$ in complete SFM, the doubling times in SFM minus haemin and in SFM minus $\mathrm{HCO}_{3}^{-}$were, respectively, $4 \cdot 1$ and $8.4 \mathrm{~h}$. Little growth occurred when both haemin and $\mathrm{HCO}_{3}^{-}$were omitted from SFM and the doubling time was $12 \cdot 8 \mathrm{~h}$. Further results showed that no growth occurred in $\mathrm{CO}_{2}$-free SFM under a gas phase of $100 \% \mathrm{~N}_{2}$ (Expt 2, Table 1). When after $96 \mathrm{~h}$ the gas phase was changed to $90 \% \mathrm{~N}_{2} / 10 \% \mathrm{CO}_{2}(\mathrm{v} / \mathrm{v})$, an immediate spurt in growth was observed and the final yield was comparable to that in SFM sparged with $100 \% \mathrm{CO}_{2}$. These results clearly indicate that $C$. pyogenes has an obligate requirement for $\mathrm{CO}_{2}$ for growth.

\section{Peptide requirement for growth}

Decreased growth in SFM minus Trypticase suggested that peptide(s) might be stimulatory or required for the growth of $C$. pyogenes. To investigate this further, Trypticase and yeast extract in SFM were replaced by a defined mixture of purines and pyrimidines, trace minerals and vitamins. Growth in this modified serum-free medium (MSFM) was negligible $\left(A_{600}=0.05\right)$. Only a slight increase in yield was seen on addition of a defined mixture of 18 free amino acids to MSFM. In contrast, single addition of Trypticase to MSFM gave growth yield equivalent to $75 \%$ of that observed in SFM. Addition of both Trypticase and amino acids resulted in growth equivalent to that obtained in SFM, but only after incubation for $44 \mathrm{~h}$. Substitution of BactoCasitone (Difco) for Trypticase yielded similar growth. However, many commercially available peptides (Sigma) including Gly-Gly-Gly, His-His, Ala-Met, Ala-Phe, Gly-Val, Leu-Gly-Gly, Gly-Asp, Gly-Try, glutathione, oxytocin, eledoisin-related peptide and polyproline could not substitute for Trypticase. The requirement for Trypticase or Casitone, even in the presence of a full complement of amino acids, suggested that $C$. pyogenes has a peptide(s) requirement for growth. Peptide requirement for growth even in the presence of a full complement of amino acids has been shown for other bacteria (Kihara et al., 1952; Pittman \& Bryant, 1964). A tryptic digest of casein was previously shown to be stimulatory or required for the growth of other strains of $C$. pyogenes (Skerman, 1966).

\section{Effect of haemin and $\mathrm{HCO}_{3}^{-}$on glucose fermentation by $\mathrm{C}$. pyogenes}

The objective of this experiment was to determine the effect of omitting haemin or $\mathrm{HCO}_{3}^{-}$ from SFM on metabolic products produced.

Dramatic changes in metabolism of this organism were noted in media from which different constituents were omitted as compared to that observed in SFM. Acetate, succinate and formate were the major fermentation products in SFM and accounted for about $87 \%$ of the products of glucose fermentation; lactate accounted for $13 \%$ of the product carbon. A trace amount of pyruvate was produced. Lactate was the major product ( $88 \%$ of the total carbon produced) when $\mathrm{HCO}_{3}^{-}$was omitted. Succinate, acetate, pyruvate and formate together accounted for $12 \%$ of the carbon produced. These results, together with the previous observation that in Tryptose broth (Difco) or Brain Heart Infusion broth (BBL) C. pyogenes produced major amounts of lactate and minor amounts of acetate (Reddy et al., 1977; Reddy \& Kao, 1978), indicate that lactate and succinate are alternate fermentation products under different growth conditions. Increased acetate production in SFM, in comparison to that in SFM minus $\mathrm{HCO}_{3}^{-}$, would be expected to yield additional ATP by substrate phosphorylation and this may explain in part the higher yield observed in this medium. The results also suggest that in SFM C. pyogenes apparently fixes $\mathrm{CO}_{2}$ (or $\mathrm{HCO}_{3}^{-}$) to produce succinate. This succinate pathway, demonstrated previously in other bacteria, is known to yield additional ATP coupled to fumarate reduction to succinate (Buchanan \& Pine, 1967; Kröger, 1974; Macy et al., 1973; Reddy \& Peck, 1978; Jacobs \& Wolin, 1963; deVries et al., 1974; White et al., 1962). If energy is conserved during fumarate reduction by $C$. pyogenes, this would explain the higher yields associated with increased succinate production in SFM (Table 1). The above results also indicate that $C$. pyogenes is metabolically more similar to Actinomyces (Buchanan \& Pine, 1967) than to lactic acid bacteria as previously suggested (Barksdale, 1970; Cummins et al., 1974). 
Lactate was the major product in the absence of haemin and accounted for $60 \%$ of the product carbon; acetate, formate and succinate together accounted for $13 \%$ of the product carbon. Haemin is required for the synthesis of a $b$ - or $c$-type cytochrome which mediates the energyconserving reduction of fumarate to succinate. As previously reported, haemin also appears to be required for $b$-type cytochrome synthesis in C.pyogenes (Reddy et al., 1977; Cornell \& Reddy, 1979).

Journal article no. 9200 from the Michigan Agriculture Experiment Station.

\section{REFERENCES}

ANonymous (1973). BBL Manual of Products and Laboratory Procedures, p. 163. Maryland, U.S.A.: BBL Microbiology Systems.

BARKSDALE, L. (1970). Corynebacterium diphtheriae and its relatives. Bacteriological Reviews 34, 348-422.

Bruner, D. W. \& Gillespie, J. H. (1973). In Hagan's Infectious Diseases of Domestic Animals, 6th edn, pp. 308-323. Ithaca: Cornell University.

Buchanan, B. B. \& Pine, L. (1967). Path of glucose breakdown and cell yields of a facultative anaerobe, Actinomyces naeslundii. Journal of General Microbiology 46, 225-236.

Buxton, A. \& Fraser, G. (1977). In Animal Microbiology, Vol. 1: Immunology, Bacteriology, Mycology, Diseases of Fish and Laboratory Animals, pp. 178179. Oxford: Blackwell Scientific.

Caldwell, D. R. \& BRyant, M. P. (1966). Medium without rumenfluid for nonselective enumeration and isolation of rumen bacteria. Applied Microbiology 14, 794-801.

Chlosta, E. M., Richards, G. K., Wagner, E. \& Holland, J. F. (1970). An opportunistic infection with Corynebacterium pyogenes producing empyema. American Journal of Clinical Pathology 53, 167-170.

Cornell, C. P. \& Reddy, C. A. (1979). Relationship between growth yields and fermentation products of Corynebacterium pyogenes in media with and without $\mathrm{HCO}_{3}^{-}$and/or hemin. Abstracts of the Annual Meetings of the American Society for Microbiology p. 41.

Cummins, C. S., Lelliott, R. A. \& Rogosa, M. (1974). Genus Corynebacterium. In Bergey's Manual of Determinative Bacteriology, 8th edn, pp. 602-617. Edited by R. E. Buchanan \& N. E. Gibbons. Baltimore: Williams \& Wilkins.

Dehority, B. A. (1971). Carbon dioxide requirement of various species of rumen bacteria. Journal of Bacteriology 105, 70-76.

Ford, J. E., Perry, K. D. \& Briggs, C. A. E. (1958). Nutrition of lactic acid bacteria isolated from the rumen. Journal of General Microbiology 18, 273-284.

Holdeman, L. V. \& Moore, W. E. C. (1975). Anaerobe Laboratory Manual. Blacksburg, Virginia, U.S.A.: V.P.I. Anaerobe Laboratory.

JACOBS, N. J. \& WoliN, M. J. (1963). Electron transport system of Vibrio succinogenes. I. Enzymes and cytochromes of the electron transport system. Biochimica et biophysica acta 69, 18-28.

Kihara, H., McCullough, W. G. \& Snell, E. E. (1952). Peptides and bacterial growth. I. L-Alanine peptides and growth of Lactobacillus casei. Journal of Biological Chemistry 197, 791-800.

KRÖGER, A. (1974). Electron-transport phosphorylation coupled to fumarate reduction in anaerobically grown Proteus rettgeri. Biochimica et biophysica acta 347, 273-289.

Macy, J., Probst, I. \& Gottschalk, G. (1973). Evidence for cytochrome involvement in fumarate reduction and adenosine 5 -triphosphate synthesis by Bacteroides fragilis grown in the presence of hemin. Journal of Bacteriology 123, 436442.

Pittman, K. A. \& Bryant, M. P. (1964). Peptides and other nitrogen sources for the growth of Bacteroides ruminicola. Journal of Bacteriology 88, 401-410.

RedDY, C. A. \& KaO, M. (1978). Value of acid metabolic products in identification of certain corynebacteria. Journal of Clinical Microbiology 7, $428-433$.

RedDy, C. A. \& PeCK, H. D., JR (1978). Electron transport phosphorylation coupled to fumarate reduction by $\mathrm{H}_{2}$, and $\mathrm{Mg}^{2+}$-dependent adenosine triphosphatase activity in extracts of the rumen anaerobe Vibrio succinogenes. Journal of Bacteriology 134, 982-991.

Reddy, C. A., Cornell, C. P. \& KaO, M. (1977). Hemin-dependent growth stimulation and cytochrome synthesis in Corynebacterium pyogenes. Journal of Bacteriology 130, 965-967.

Reddy, C. A., Cornell, C. P. \& Fraga, A. M. (1980). Chemically defined growth medium for Corynebacterium pyogenes. American Journal of Veterinary Research 40, 843-845.

SKERMAN, T. M. (1966). Comparative studies of coryneform bacteria of animal origin, with special reference to their nutrition. Ph.D. thesis, University of Reading, U.K.

SмiтH, J. E. (1966). Corynebacterium species as animal pathogens. Journal of Applied Bacteriology 29, 119 130.

Vega, L. E. \& Gavan, T. L. (1970). Corynebacterium pyogenes-a pathogen in man. Report of a case Cleveland Clinical Quarterly 37, 207-214.

DEVRIES, W., VANWIJEK-KAPTEYN, W. M. C. \& OOSTERHUIS, S. K. H. (1974). The presence and function of cytochromes in Selenomonas ruminantium, Anaerovibrio lipolytica and Veillonella alcalescens. Journal of General Microbiology 81, 69-78.

White, D. C., Bryant, M. P. \& Caldwell, D. R. (1962). Cytochrome-linked fermentation in Bacteroides ruminicola. Journal of Bacteriology 84, 822-828. 